\title{
The House of Commons: control of government and citizen representation
}

How well does the House of Commons work via floor debates, questions to ministers and as a general means of scrutinising and passing legislation, and monitoring policy implementation? Has the return of a hung parliament since 2017 changed how the House of Commons functions as a legislature? Artemis Photiadou and Patrick Dunleavy consider if the traditional model of Parliament as primarily supporting a showcase political clash of government and opposition has changed to make the Commons a more effective focus of national debate or to create stronger control of the executive.

\section{What does democracy require for the legislature?}

(i) Focusing national debate, and scrutinising and controlling major decisions by the executive

The elected legislature should normally maintain full public control of government services and state operations, ensuring public and parliamentary accountability through conditionally supporting the government, and articulating reasoned opposition, via its proceedings.

The House of Commons' floor debates and question times should be a critically important focus of national political debate, articulating 'public opinion' in ways that provide useful guidance to the government in making complex policy choices.

Legislators should regularly and influentially scrutinise the current implementation of policies, and the efficiency and effectiveness of government services and policy delivery.

Individually and collectively legislators should seek to uncover and publicise issues of public concern and citizens' grievances, giving effective representation both to majority and minority views, and showing a consensus regard for serving the public interest. 


\section{(ii) Passing laws and controlling the executive's detailed policies}

In the preparation of new laws, the legislature should supervise government consultations and help ensure effective pre-legislative scrutiny.

In considering legislation, Parliament should undertake close scrutiny in a climate of effective deliberation, seeking to identify and maximise a national consensus where feasible.

Ideally pre-legislative scrutiny will ensure that the consequences of new laws are fully anticipated, changes are made to avert 'policy disasters' and risks are assigned to those societal interests which can most easily insure against them.

\section{Recent developments}

If the parliament elected in June 2017 endures for five years, as by law it could and should, then by June 2022 the UK will have experienced ten years of hung parliaments out of the last 12. The Conservative-Liberal Democrat coalition government of 2010-15 would be joined by up to five years of a Tory minority government sustained in office by a 'confidence and supply' agreement with the Democratic Unionist Party (DUP). One year of minority government has already passed as we write. In between these supposedly 'unusual' peacetime conditions, there would be only a single year's inter-regnum (2015-16) when the Cameron government had a small but clear overall majority and operated on the traditional patter. There was also a further year of Tory majority government under May, but it was marked by a good deal of post-Brexit Leaver-Remain conflicts that made her parliamentary situation very weak.

All of this might make the 'Westminster system' of disproportional elections producing 'strong' majority governments, and the associated 'British political tradition' look more suspect than ever before. But how far has it affected how the House of Commons operates? In particular, has it transferred power over policy-making from the executive to Westminster, or from ministers to MPs acting as a body, or to the opposition, or to backbenchers in the governing party?

In the Conservative and Liberal Democrats coalition (2010-15) - the first in peacetime since 1945 - David Cameron as Prime Minister was uniquely exposed to right-wing Tory backbenchers and centre-left Liberal Democrats dissenting from government policies. Philip Cowley showed that, not surprisingly, some level of backbench dissent affected $35 \%$ of Commons divisions in 2010-15, a post-war record (with the Labour government of 2005-10 as the nearest parallel). Yet how much did any of this matter? A listing of explicit government defeats in the Commons shows only six for the Cameron coalition, of which two were minor ambushes by the opposition and one a private members' bill. In 2015-16 there were two substantial votes against government policy supported by Tory MPs, but none between June 2016 and the 2017 general election under May.

Since Theresa May lost her majority, the government has been defeated on 13 Commons votes, of which the most serious was an amendment to a Brexit bill to give Parliament a vote on the final Brexit deal. Ministers have also had several narrow escapes (for example, 
a win by three votes in July 2018). Two other defeats are Brexit-related, three concerned the Universal Credit reform of social security (which was running into many problems that ministers seemed to be in denial about) and two others reflected the 2017 electorate's message to the government that pay austerity in the public sector had gone on for too long. Suggestions that Tory MPs in particular had now got the habit of dissenting were also buttressed in the Queen's Speech debate in June 2017, when Labour backbencher Stella Creasy tabled a relevant amendment to fund abortion operations in mainland UK for women from Northern Ireland - and the government was forced to agree the change in order to avoid a defeat.

This example shows the familiar limits of only looking at explicit defeats that follow from the 'rule of anticipated reactions'. This says that if $B$ always does what $A$ says, this may be due to $A$ being so powerful that B must always comply; or to B being so powerful that $A$ never proposes anything they will vote down; or to some mix of the two. Much of MPs' influence over public policies undoubtedly takes the form of ministers amending or abandoning proposals to forestall defeats - as May did in July 2018 by accepting four Brexiteer amendments to avoid a defeat over the government's Brexit strategy.

\section{Strengths, Weaknesses, Opportunities, Threats (SWOT) analysis}

\section{Current strengths}

The House of Commons' long history, and its key position cross-nationally as an exemplar of sound parliamentary practice, give MPs a strong sense of corporate identity. This clearly motivates some public interest behaviours that blur otherwise rancorous partisanship.

\section{Current weaknesses}

The Commons is executive-dominated, with MPs most often voting on 'whipped' partisan lines. Party cohesion has weakened, but is still exceptionally high by cross-national standards. 


\section{Current strengths}

The collaboration of government and opposition to manage the Commons also contributes to a certain degree of elite self-restraint and avoidance of unconstrained partisanship that is essential to the operations of the UK's 'unfixed' constitution.
Some parliamentary institutions operate effectively, engaging the attention of MPs, media and the public - especially Prime Minister's Question Time (and to a lesser degree, ministers' question times), and the operation of select committees (see Chapter 4.2).
The post hoc scrutiny of policy implementation via select committees has greatly improved the Commons' role since 1979 , adding to previous strengths in post hoc financial scrutiny (see Chapter 4.2).

\section{Current weaknesses}

The top two parties are not only normally over-represented in terms of MPs vis-à-vis their vote share, but also collude to run Westminster business in a 'club way' (for example, via whips' cooperation, and archaic bodies like the Privy Council). These practices maximise their joint power but exclude from influence all small parties. A disastrous combination of these two biases produced a Commons walkout by SNP MPs in June 2018, when all the devolution aspects of the main Brexit bill - the European Union (Withdrawal) Bill - were allocated a derisory 15 minutes' debating time.

In 2015, the Tory government unilaterally made $19 \%$ cuts in the state funding given to opposition parties in Parliament (known as short money). The move inhibited their ability to conduct parliamentary business and critique ministers effectively, without making any worthwhile savings. In 2017-19 nearly $80 \%$ of the money will go to Labour, with the SNP next.

Only a few component parts of the legislature's activities work well. Much time and energy is consumed in behaviours that are ritualistic, point-scoring and unproductive in terms of achieving policy improvements as when a Tory MP shouted 'object' to block a 2018 private members' bill against 'upskirting' that enjoyed almost universal support.

Anachronistic and time-wasting division voting procedures are also used in a digital era. Most attempted modernisations remain stalled on traditionalist MPs' objections.

The Commons' ex ante budget control is non-existent. Finance debates on the floor of the House are simply general political talkfests for the government and opposition. Parliamentary 'estimates' are odd, specially constructed and out-of-date numbers, of declining value in relation to the real dynamics of public spending. 


\section{Current strengths}

Moves to make the Commons more familyfriendly and its culture more diverse are having some success.
MPs' small constituencies have fuelled their role as grievance-handlers for constituents having trouble with public services, which has expanded in recent years.
The Liaison Committee's generalist sessions with the Prime Minister (ranging across a wide set of policy areas) are a useful if modest innovation.
The Backbench Business Committee enables backbenchers to raise topics for debate in a more effective way, adding to the Commons' overall steering capabilities.

\section{Current weaknesses}

The Commons meets in a museum building, surrounded by a Victorian empire grandeur that helps perpetuate a culture amongst MPs that is always male-orientated, white, club-like, and obsessed with the 'privileges' of MPs. Debates and other sessions are often 'shouty' and visibly anti-deliberative. Much more could be done at zero cost to make the Commons more women- and family-friendly, and to normalise its now odd culture.

On matters affecting their own welfare, MPs are self-governing, self-interested and routinely dismissive of ordinary citizens' concerns (c.f. repeated MPs' expenses scandals and recent austerity-busting pay rises). Some $30 \%$ of MPs have second jobs. MPs also run their own offices as small businesses, employing whom they like. So, some do a good job and others perform poorly.

At $650 \mathrm{MPs}$, the House of Commons is an exceptionally large legislature. Most MPs don't have enough useful things to do (hence the second jobs held by three in ten, and a plethora of ethically dubious 'outside interests').

The government has created a huge "payroll vote' of ministers and unpaid pseudoministers on the first rung of a promotion ladder, simply to help maintain control of these excess numbers by dangling a chance for preferment.

Fuelled by the coalition period, and the post-2017 hung parliament, the amount of secondary legislation is growing. Primary legislation is increasingly drafted in ways that leave its consequences obscure, to be filled in later via statutory instruments or regulation. Commons scrutiny of such 'delegated legislation' is very weak and ineffective. 


\section{Current strengths}

MPs can raise issues with the government though Early Day Motions (EDMs), very few of which are ever debated. Many topics tend to be trivial. The Procedure Committee in 2013 nonetheless found that there should be no changes. EDMs have generally declined.

\section{Future opportunities}

E-petitions started via Parliament in 2015. They give the public a new opportunity to raise issues with the government by triggering a parliamentary debate if 100,000 signatures are obtained. By June 2017, over 31,730 petitions had been launched, twothirds of which were rejected, but nearly 11,000 accepted. Only 65 were debated in Parliament. In these two years 31 million signatures were added to petitions, and 14 million discrete email addresses used. So far this popular option has proved inconsequential in changing policies, though it is an effective way for groups to raise public awareness or show public discontent (nearly 1.8 million people signed a petition to ban President Trump visiting the UK - he still did, but he did not come to Westminster).

The Parliament website is very large but poorly structured and hard to use.

\section{Current weaknesses}

\section{Future threats}

Enacting the English votes for English laws (EVEL) change via changing Commons' standing orders sets a thoroughly dangerous constitutional precedent, outside all judicial review. If a Commons majority alone can tell MPs in one part of the country that they cannot vote in a newly created but decisive Westminster procedure, what is to stop another majority imposing the same exclusion on MPs of a given party?

Large distortions in the regional representation of parties (for example, the almost elimination of non-SNP parties in Scotland 2015-17) further reduces the legislature's already tattered representativeness under first-past-the post voting. 


\section{Future threats}

If and when a Brexit agreement is reached, current EU law in force in the UK will need to be converted into domestic law (and in certain cases be 'corrected' before being converted). Such changes, as instituted by the EU Withdrawal Act, will be made by ministers and not be subject to the usual parliamentary scrutiny. The Lords Constitution Committee called this prospect a 'massive transfer of legislative competence' into the Government's hands. It raises major questions about the right balance between executive and legislature power, especially in the period 2017-20.

Many MPs and select committees have only made limited steps to connect with voters via social media.

\section{Parliamentary consideration of treaties and military actions}

The royal prerogative consists of those powers of the medieval absolute monarchs that are not yet regulated by statute law. They are exercised on the Crown's behalf by ministers, especially the Prime Minister. Historically the Prime Minister and government have retained the prerogative ability to go to war and to ratify treaties. The Commons has only been able to vote on these decisions after the fact and in restrictive ways - for example, via moving a no confidence motion in the government. The Constitutional Reform and Governance Act 2010 curtailed the treaty-ratifying power and put it on a statutory basis. Its provisions will be very important if the withdrawal agreement from the $\mathrm{EU}$ will be in the form of a treaty, as this would require the approval of the UK Parliament (and of the EU Parliament) before it became binding.

The ability to commit UK armed forces to war appears to have been replaced through a new convention that MPs should vote on major actions before they are undertaken. But earlier promises made by Gordon Brown and William Hague that formal changes would be made have not been acted on, so that a Prime Minister can still do things without explicit parliamentary authorisation. The complex history of UK involvement in Syria is an example. In August 2013, MPs defeated a proposal by the coalition government to take military action against the Assad government in Syria. A year later a diametrically opposite motion for air strikes against IS (Islamic State) in Iraq (but not in Syria) was approved by the Commons. In December 2015, the Tory government won a vote with a majority of 174 to extend anti-IS airstrikes to Syria. In April 2018 May approved air strikes in Syria without consulting the Commons, and in July despatched 440 more UK troops to Afghanistan. The early parts of this sequence would seem to suggest that the power to go to war is now subject to approval by the Commons, but the later ones would not. Similarly, in mid-2016 it emerged that some UK ground forces were being secretly deployed in anti-IS actions in Libya, without even any notification to Parliament. 


\section{What do fixed-term parliaments mean?}

Almost the only major constitutional changes to survive from the 2010-15 coalition government period is the Fixed-term Parliaments Act 2011. This requires that general elections are held every five years, unless either:

(i) the government loses a vote of confidence, the Prime Minister resigns and no other government can be formed; or

(ii) two-thirds of MPs vote for an earlier dissolution, which would normally require that (most) MPs from both the government and the main opposition parties support the motion.

Nick Clegg saw fixed terms as a key safeguard against Cameron calling an election early and terminating the coalition with the Liberal Democrats at a time when they might suffer - but his party's support fell by two-thirds anyway at the end of the government. The Act initially made the Tories look like a strong beneficiary, with a five-year term apparently securely guaranteed to Cameron in 2015.

Yet May's decision in April 2017 to 'call' an early election for June changed all that. It produced a defiant 'bring it on' reaction from Jeremy Corbyn and Labour MPs, despite their party being 20 percentage points behind in the early opinion polls. A supermajority of 522 to 13 MPs backed the government's motion for a new election, at which voters subsequently went on to deny the Conservatives a majority. Where does this leave the FTP law? Clearly it could be another piece of completely dud legislation, if every future opposition always feels compelled by bravado to say yes to any dissolution. On the other hand, May's disastrous choice in 2017 confirmed UK voters' dislike of unnecessary elections, and so is likely to deter any future Prime Minister with a majority from going back to voters before at least a four-year gap from the last election - which was already the historical status quo ante.

Another area of ambiguity exists. If the Prime Minister of a majority party resigns, as David Cameron did in June 2016, and the governing party chooses a new leader, she is automatically asked by the Queen to form a government. However, should the Prime Minister lose a no-confidence vote instead, the process to be followed under FTP is still unclear. Some commentators on FTP claim that the monarch's role here has been completely excluded, and so a robo-law transition to a new election must follow immediately from a no-confidence vote in a Prime Minister. However, within a 14-day period under the Act, could the monarch ask another member of the largest party to try to form a government without any immediate dissolution (since no party leadership election could easily be organised in that time)? Or does she then ask the Leader of the Opposition to perhaps form a minority government?

\section{Scrutiny of the executive}

The Prime Minister's active participation in parliamentary proceedings is a key mechanism for ensuring the accountability of the executive, but they have been less and less present in the Commons since the time of Thatcher and Blair. The Prime Minister's attendances are now 
limited to a single 30-minute question time (PMQs) once a week when Parliament is sitting, occasional speeches in major debates, and periodic public meetings with the chairs of select committees in the Liaison Committee. More encouraging is recent research showing that backbenchers used PMQs in 1997-2008 as a key public venue, with backbenchers often leading the agenda and breaking new issues that later grew to prominence. As Leader of the Opposition, Jeremy Corbyn has experimented with using PMQs to ask questions sent in on email by the public, somewhat changing the tone of the session.

\section{The 'payroll vote'}

Parliament's independence vis-à-vis the executive has long been qualified by strong partisan loyalties amongst almost all MPs, who (after all) have spent many years working within parties before getting into the Commons. The members of the government's frontbench are expected to always vote with the executive, as are parliamentary private secretaries (who are unpaid pseudo-ministers). The last official data of the payroll vote in 2010 showed that approximately 140 MPs are affected. Unofficial estimates of the size of the payroll vote suggest that by 2013 it was equivalent to well over a third of government MPs. Given the small number of Conservative MPs in the 2015 and 2017 parliaments, the ratio will still be high. If the Commons seats ever do fall to 600 , then the prominence of the payroll vote would increase, unless government roles for MPs were cut back.

\section{EVEL: English votes for English laws}

In the 2014 Scottish independence referendum, Labour and the Liberal Democrats joined with the Tories to solemnly pledge major new powers for the Scottish Parliament. The morning after the result Cameron announced a previously hidden codicil to this deal, that English and Welsh MPs would vote alone in the Commons on laws just affecting them.

This potentially substantial constitutional change was then bounced through by the 2015 Tory majority amending the House of Commons' standing orders - with no real public consultation, no House of Lords approval needed, no Supreme Court decision on the scheme and no judicial review. A new 'England-only' committee stage came in for laws affecting only England (and including Welsh MPs for English and Welsh laws) with a pingpong process between the committee and full House (including Scottish and Northern Ireland MPs) possible at report stage. At the close of the Commons' consideration, a Legislative Grand Committee of only England MPs would then vote to accept or reject the final bill as a whole. The House of Lords process for these laws was not changed, but a Commons Grand Committee composed of only English MPs now considers any Lords amendments, as well as full the Commons. The Speaker is also repeatedly involved in determining which laws or provisions within laws must be subject to this process. The Public Administration and Constitution Committee's 2016 report on EVEL was highly critical.

Academic research into EVEL's first year of operation found that the process is too complex; that English and Welsh MPs have the power to veto laws passed by the entire House; that the process undermines the coherence of UK-wide government; and that it 
fails to facilitate a meaningful expression of England's voice. Whether the scheme will be much used, and if it can survive a non-Tory majority, both seem unclear at present. The Conservatives anticipated being the great beneficiaries of the EVEL change, but they now depend on the votes from Northern Ireland MPs in the DUP in order to pass any UK legislation.

\section{Conclusions}

Public confidence in Parliament was badly damaged by the expenses scandals of 2009 , and trust in the House of Commons remains at a low ebb, despite some worthwhile but modest reforms in the interim, which made select committees more effective in scrutinising government (see Chapter 4.2). The Commons remains a potent focus for national debate - but that would be true of any legislature in most mature liberal democracies. There is no evidence that the UK legislature is especially effective or well-regarded, as its advocates often claim. Structural reforms to make the Commons a more effective legislature, and to modernise ritualistic behaviours and processes, are still urgently needed.

Five years of coalition government between 2010 and 2015 and a return to a hung parliament since 2017 have both somewhat reduced executive predominance over Parliament - as they were almost bound to do. In addition, the effect of Brexit in crosscutting party lines (see Chapter 3.1) produced a highly complex set of votes in the Commons on relevant laws. At several points, legislative progress seemed almost deadlocked in 2018. Perhaps any more powerful legislature may operate like this - as often getting grid-locked as it provides a clear, independent lead on policy choices. Critics of Parliament have easily interpreted this experience as MPs trying to 'frustrate' the 2016 referendum verdict.

Yet even such major developments as these may not break the tradition of strong executive control over the Commons. After the 2017 general election there were some signs of an amelioration of party discipline and more cross-party working in the public interest being possible (for example, in MPs insisting that the Universal Credit reorganisation of welfare payments be improved). Yet these proved to be temporary.

Artemis Photiadou is Research Associate in the London School of Economics and Political Science's Public Policy Group and a PhD candidate at LSE's International History Department. She is also the Managing Editor of LSE British Politics and Policy blog.

Patrick Dunleavy is Professor of Political Science and Public Policy at the LSE and coDirector of Democratic Audit there. He is also Centenary Professor in the Institute for Governance and Policy Analysis (IGPA), University of Canberra. 